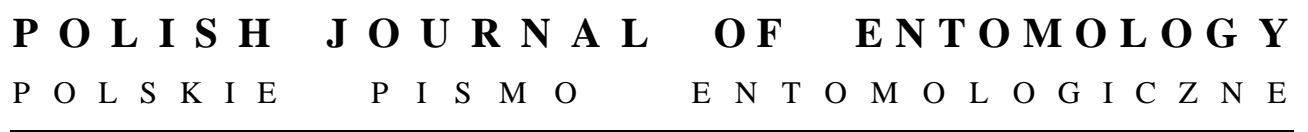

VOL. 84: 49-59

Lublin

30 April 2015

DOI: 10.1515/pjen-2015-0005

\title{
An unexpected record of Myrmica schencki EMERY, 1895 as a secondary host ant of the hygrophilous form of a small and isolated population of the Alcon Blue butterfly Phengaris (=Maculinea) alcon (DENIS et SCHIFFERMÜLLER, 1775) (Lepidoptera, Lycaenidae) in NE Poland
}

\author{
MARCIN SIELEZNIEW ${ }^{1}$, CEZARY BystrowsKi ${ }^{2}$, KRZYSZTOF DeONIZIAK $^{3}$, \\ JoÃo Matos Da COSTA ${ }^{4}$
}

${ }^{1}$ Department of Invertebrate Zoology, Institute of Biology, University of Bialystok,

Ciołkowskiego 1J, 15-245 Białystok, Poland, e-mail: marcins@uwb.edu.pl

${ }^{2}$ Forest Research Institute, Department of Forest Protection, Sękocin Stary, 05-090 Raszyn,

Poland, e-mail: C.Bystrowski@ibles.waw.pl

${ }^{3}$ Department of Behavioural Ecology, Adam Mickiewicz University, Umultowska 89,

61-614, Poznań, Poland, e-mail: krzysiekdeo@gmail.com

${ }^{4}$ Narew National Park, Kurowo 10, 18-204 Kobylin Borzymy, Poland, e-mail: costajoaom@gmail.com

\begin{abstract}
Phengaris alcon is a socially parasitic butterfly species showing ecological variation across its distribution range. Host ant specificity was studied on a site (a mineral island surrounded by wetlands) in the Narew National Park in NE Poland, inhabited by a highly isolated and small population (estimated at several dozen individuals). We examined nests of their potential hosts, i.e. Myrmica ants, in patches of habitat where the initial larval food plant i.e. Gentiana pneumonanthe was recorded. The Myrmica species composition was shown to be unusual for such habitats because of the presence of $M$. schencki together with the dominant M. scabrinodis. In 2013 we found just one prepupa of $P$. alcon in a nest of $M$. schencki, which had never yet been recorded as a host of the hygrophilous form of this butterfly, and none of the M. scabrinodis nests were infested. However, in 2014 a very typical pattern for eastern Europe was observed, i.e. larvae were recorded exclusively in $M$. scabrinodis colonies and the parasitisation rate was $33 \%$. In both seasons we recorded similar numbers of egg shells on gentians, which indicated a similar population size of adult butterflies. The results are discussed in the context of the ecology and conservation of $P$. alcon as well as the sampling design.
\end{abstract}

KEY WORDS: Phengaris alcon, Maculinea, Myrmica schencki, Myrmica scabrinodis, myrmecophily, host ant specificity, Gentiana pneumonanthe, Narew National Park. 


\section{INTRODUCTION}

The vulnerability of the Alcon Blue Phengaris (=Maculinea) alcon (DENIS et SCHIFFERMÜLLER, 1775) (Lepidoptera: Lycaenidae) is due largely to its complicated life history, including the dependence of successful larval development on the simultaneous presence of two vital resources. Females oviposit on flowerheads or, rarely, on the young leaves of certain gentians. $P$. alcon females choose gentian plants for oviposition, probably based on plant characteristics rather than ant cues (FÜRST \& NASH 2009, WYNHOFF et al. 2015). The first three caterpillar instars (i.e. in the first 2-3 weeks of life) are endophytic, feeding on developing seeds. After the third and final moult, they leave the plants and drop to the ground. There, if they are lucky, they are encountered and adopted by foraging Myrmica LATREILLE, 1804 ants (THOMAS 1995), as they mimic the ants' chemicals (THOMAS et al. 2013) and also their acoustic signals (BARBERO et al. 2009). In the colonies, they become social parasites in that they are fed directly by workers and in addition eat some of the hosts' brood (THOMAS \& ELMES 1998). They spend about 9-10 months under ground; there they pupate and eventually leave their hosts' nests the next summer as adults.

Phengaris alcon shows considerable ecological variation across its distribution range, and local populations are adapted to different larval food plants and ants. As a consequence, quite different habitats can be used. Two main ecotypes are distinguished, which are sometimes still considered distinct species, i.e. P. alcon and P. rebeli (HIRSCHKE, 1904). $P$. 'alcon' inhabits wet meadows, lightly grazed pastures, wet heathlands and fens, and the main larval food plant is Gentiana pneumonanthe LINNAEUS, 1753. In contrast, $P$. 'rebeli' prefers dry calcareous grasslands where Gentiana cruciata LinNAEUS, 1753 occurs (THOMAS 1995).

Genetic data and morphological analyses show that treating $P$. 'alcon' and P. 'rebeli' as good species is unjustified (ALS et al. 2004, BERECZKI et al. 2005, FRIC et al. 2007, SIELEZNIEW et al. 2012). Moreover, recent studies by TARTALLY et al. (2014) revealed that $P$. rebeli at its type locality (meadows in the Styrian Alps above the coniferous zone) uses Gentianella rhaetica (A. KERNER et J. KERNER, 1882) Á. LÖVE et D. LÖVE, 1961, and cannot be synonymised with the taxon using G. cruciata; it can, however, be treated as another ecological form adapted to high mountain conditions.

The use of different plants in different habitats, which may be a consequence of developmental adaptation to larval food plant phenology (SIELEZNIEW \& STANKIEWICZ 2007), is not the only level of ecological variation in these controversial taxa. Local populations also differ with respect to their host ants (ALS et al. 2004, SIELEZNIEW et al. 2012, Thomas et al. 2013). In Poland, for instance, there are three distinct ecotypes of P. alcon, which exhibit a high degree of specificity towards Myrmica ants. There are two distinct host ant races related to G. cruciata: in the Pieniny region M. schencki EMERY, 
1895 is used, whereas in the Przemyśl Foothills and Beskid Niski Mountains the caterpillars develop almost exclusively in colonies of M. sabuleti MEINERT, 1861 and M. scabrinodis NYLANDER, 1846 (SIELEZNIEW \& DZIEKAŃSKA 2009). Much more widespread are populations inhabiting wet meadows using G. pneumonanthe, and exceptionally also Gentianella amarella (LINNAEUS, 1753) BÖRNER, 1912 (SIELEZNIEW \& STANKIEWICZ-FIEDUREK 2009). The flight period of this ecotype, in July and August, usually occurs about 2-3 weeks later than the xerophilous ecotype using G. cruciata, because the caterpillars start developing quickly only after overwintering (SIELEZNIEW $\&$ STANKIEWICZ 2007). A few dozen sites are known in Poland, most of them in the southeast of the country. The main host ant is M. scabrinodis; only in the Świętokrzyskie region is the closely related species M. vandeli BONDROIT, 1920 (probably a temporary social parasite of M. scabrinodis) simultaneously used (SIELEZNIEW \& STANKIEWICZ 2004b, SIELEZNIEW \& STANKIEWICZ-FIEDUREK 2009).

The Świętokrzyskie and Lublin regions are considered as strongholds of this species in Poland. On the other hand, the butterfly is now extinct in Lower Silesia and is on the verge of extinction in Wielkopolska. In NE Poland the most important area of occurrence encompasses the Biebrza National Park (STANKIEWICZ et al. 2005a). Very recently, however, a site of $P$. alcon was discovered in the Narew National Park. The aim of the present study was to acquire insight into the ecology of this highly isolated, small and therefore vulnerable population, with particular emphasis on host ant relationships.

\section{MATERIAL AND METHODS}

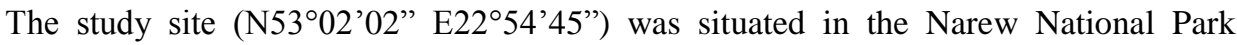
(NNP), about $500 \mathrm{~m}$ to the south of the River Narew and the village of Bokiny, situated on the other side of the river. It was discovered in 2012 (29 July), by C.B. during preparatory inventory work for a NNP Conservation Management Plan. The butterfly inhabited a 'mineral island' (a small area of higher, drier land overlying mineral soils) surrounded by wetlands. The total area of this higher land, covered mostly by light pine forest, with some aspens and birches, was about 5 ha. The habitat of the butterfly, defined by the presence of its larval food plant G. pneumonanthe, was much smaller and covered a patch of about 0.3 ha in the southern part of the mineral island (Fig. 1), where the vegetation was rather sparse and dominated by Molinia caerulea (LinnAEus, 1753) MoEnch, 1794 and Calamagrostis epigejos (LINNAEUS, 1753) ROTH, 1788. A few gentians were also growing in the central part of the mineral island in very dry places, i.e. close to patches of Thymus serpyllum LINNAEUS, 1753, and in its northern part, which had denser Filipendulion vegetation. The presence of just single eggs indicated that the latter area was only occasionally visited by 
P. alcon. Very few nectar plants were recorded at the site: the butterflies were observed nectaring on flowers of Veronica spicata LINNAEUS, 1753 and Jasione montana LiNNAEUS, 1753.

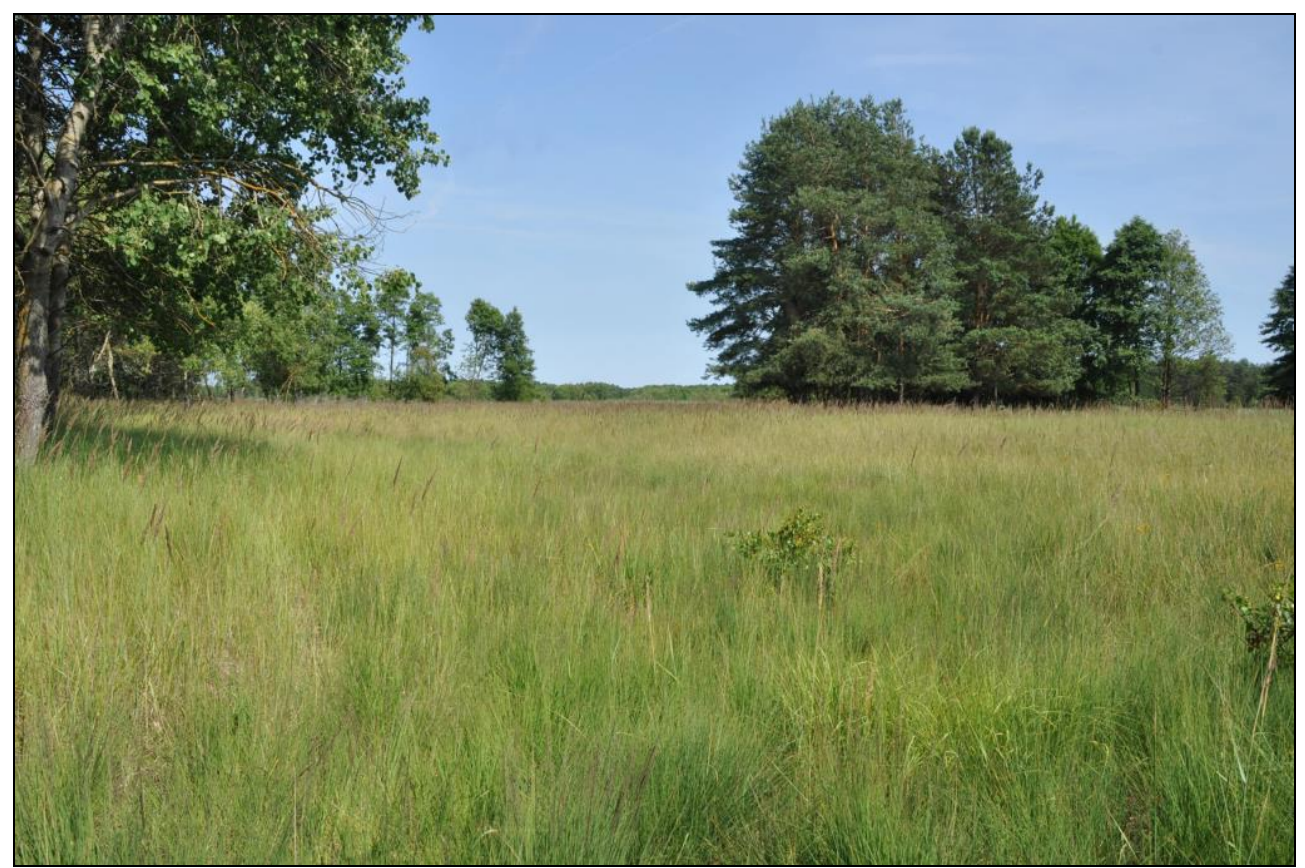

Fig. 1. View of the most important section of the Phengaris alcon site in NNP.

In 2013 (27 June), we searched for Myrmica ants in patches of habitat marked with GPS in the previous season. Later in the same season we marked larval food plants bearing eggs/egg shells more precisely with pegs. Therefore in 2014 (12 and 23 June) we searched the turf in places where the presence of nests infested by $P$. alcon was most likely. We looked for Myrmica nests within a radius of about $2 \mathrm{~m}$ from the plants, as this distance is usually assumed to be the foraging zone of Myrmica workers (ELMES et al. 1998).

All the nests found were very carefully opened and examined for the presence of P. alcon. It is known that full-grown larvae are carried by workers to the upper chambers during the day and that pupation takes place there as well (ALS et al. 2002); hence, there was no need to excavate and destroy the colonies. However, for conservation reasons (the sensitivity of a small and isolated population), we made no attempt to count all the larvae/pupae present in the infested nests, i.e. we brought our examination to an end on 
noticing $P$. alcon prematures. Finally, we covered the nests and restored the arrangement of the surrounding vegetation as exactly as possible to minimise the impact of our investigation.

Ants were preliminarily identified in the field with hand lenses, but voucher samples of 5-10 workers were collected to confirm their identification in the laboratory, according to CZECHOWSKI et al. (2012).

The significance of heterogeneity in the presence/absence of $P$. alcon in nests of different Myrmica species and in the proportions of the nests examined in different seasons seasons was tested using Fisher's exact test (as implemented at http://www.quantitativeskills.com/sisa).

Additionally, in both seasons, shortly after the end of the flight period, we counted all visible eggs/egg shells, as well as occupied and unoccupied gentians, to assess the relative population size of the butterfly.

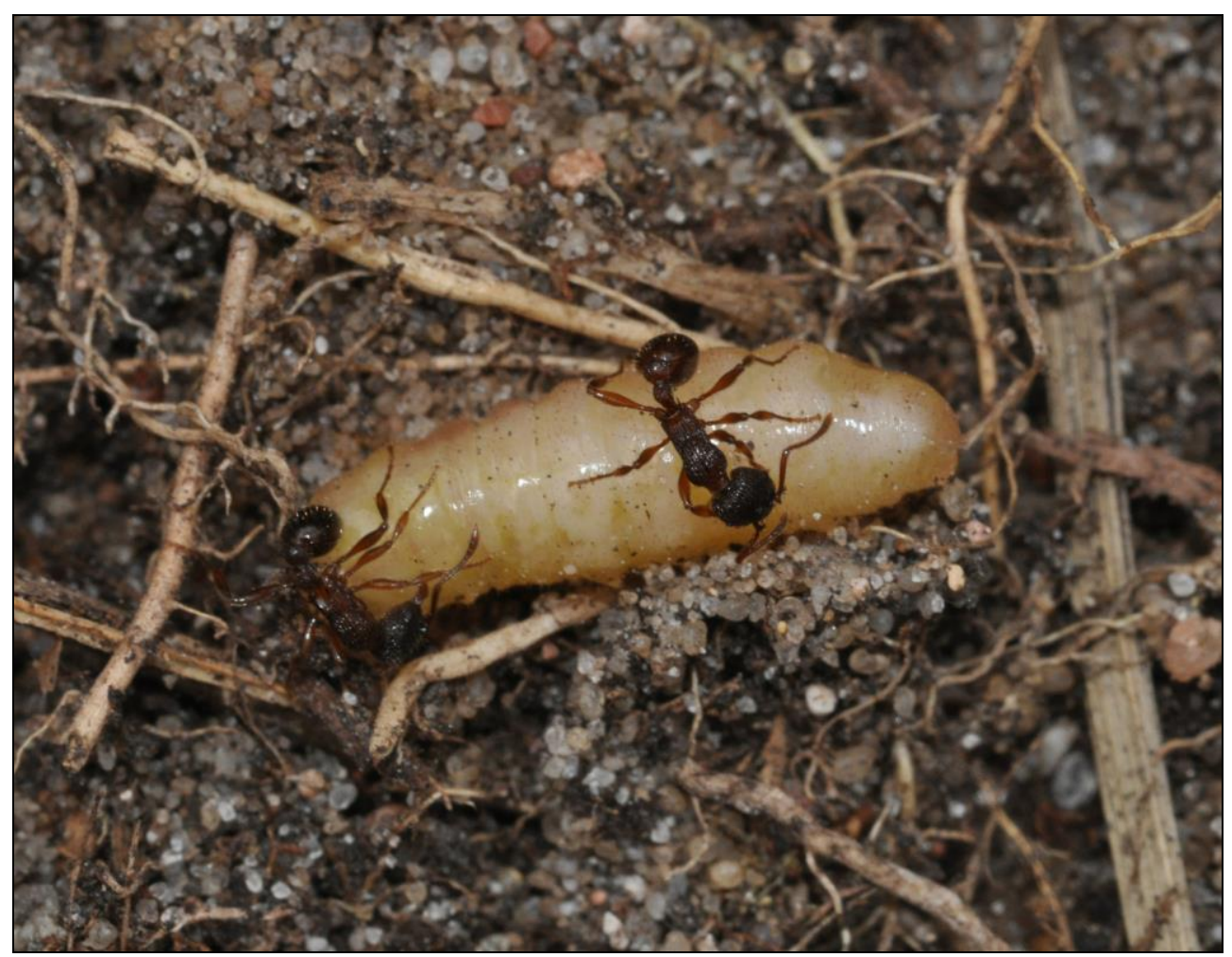

Fig. 2. Prepupa of Phengaris alcon in a nest of Myrmica schencki. 


\section{RESULTS}

In 2013 we examined 19 nests of Myrmica ants - 11 of M. scabrinodis, five of M. schencki, two of M. ruginodis NYLANDER, 1846 and one of M. rubra (LINNAEUS, 1758). Just one nest was infested, i.e. we found a prepupa in a M. schencki colony (Fig. 2).

In 2014 we examined about twice as many nests (40); again the dominant species was M. scabrinodis (30). Moreover, eight nests of M. schencki and two of M. ruginodis were found. As many as 10 M. scabrinodis nests were infested (33.3\%) and we recorded 25 individuals of $P$. alcon altogether (from one to seven larvae/prepupae in a colony) (Fig. 3). However, for the reasons of conservation mentioned earlier, we did not count all of them, so the real number could have been somewhat higher.

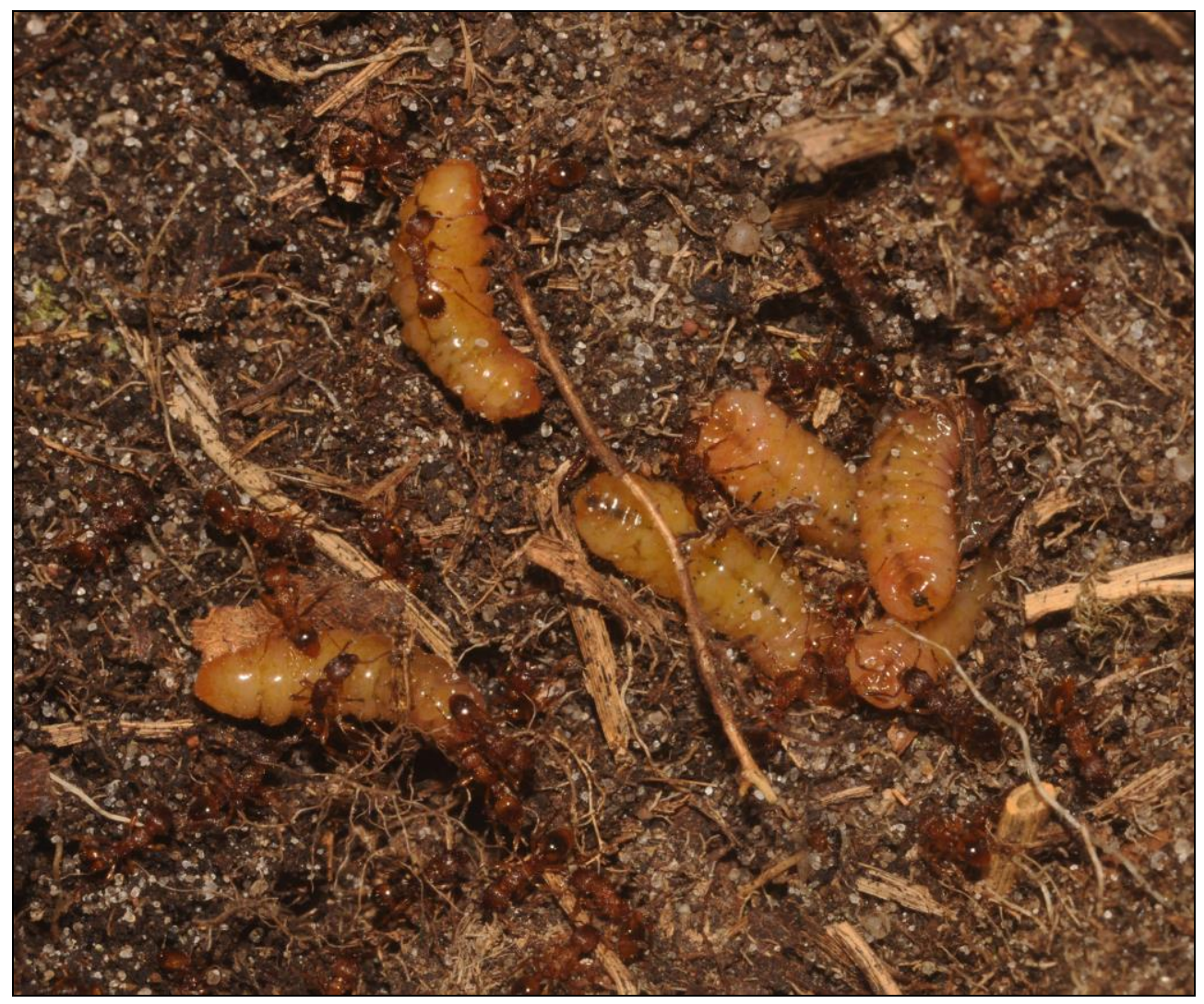

Fig. 3. Larvae of Phengaris alcon in a nest of Myrmica scabrinodis. 
Significant heterogeneity in host ant use was found between $M$. scabrinodis and M. schencki in $2014(\mathrm{p}<0.05)$ and when parasitisation of $M$. scabrinodis nests was compared between the two seasons $(\mathrm{p}<0.05)$. None of the other comparisons were significant, i.e. infestation of M. scabrinodis vs. M. schencki in $2013(\mathrm{p}=0.31)$, M. scabrinodis vs. M. schencki in both seasons ( $\mathrm{p}=0.26)$ and $M$. schencki between the two seasons ( $\mathrm{p}=0.38$ ). Neither did we find a significant difference in the species composition of Myrmica nests recorded in 2013 and $2014(\mathrm{p}=0.30)$.

The flight periods of the butterfly in 2013 and 2014 lasted from the second week of July to the end of that month. In 2013, at the end of the flight period, we counted 853 eggs/egg shells (distributed on 53 out of 82 plants found). In 2014 we counted 911 eggs/egg shells (on 42 out of 91 plants). The total number of plants at the site was probably underestimated in both seasons as some gentians, especially those not flowering, and therefore not easy to spot among the tall grasses, could have been overlooked. Almost all the plants were distributed in the main part of the site. Elsewhere only a very few eggs were detected. The very similar number of eggs and egg shells indicated similar sizes of adult populations in both seasons.

\section{DISCUSSION}

The dominance of M. scabrinodis in habitats of $P$. alcon in eastern Europe is quite typical. The only exceptions are the site in the Biebrza National Park, where this species is in a minority and the much more abundant Myrmica ant is the non-host M. gallienii BONDROIT, 1920 (SIELEZNIEW \& STANKIEWICZ-FIEDUREK 2009), and the locality in Hungary, where M. slovaca SADIL, 1951 (=M. salina RUZSKY, 1905) is used as the dominant host ant (TARTALLY et al. 2008). On the other hand, the relative abundance of M. schencki is very unusual compared to other sites with G. pneumonanthe. This ant species has not been reported from any site of this butterfly either in Poland or in Denmark, where intensive studies were carried out (ALS et al. 2002, WITEK et al. 2008, SIELEZNIEW \& STANKIEWICZ-FIEDUREK 2009). Just a single colony was recorded among over 200 nests examined during studies carried out at eight sites in Hungary and Romania (TARTALLY et al. 2008). However, M. schencki is frequently recorded on xerothermic grasslands inhabited by the ecotype using G. cruciata (STANKIEWICZ et al. 2005b, TARTALLY et al. 2008, SIELEZNIEW \& DZIEKAŃSKA 2009, THOMAS et al. 2013). M. schencki is considered a fairly xerophilous oligotope of dry grasslands and forests, where it inhabits sunny patches. It prefers light soils with poor herbaceous vegetation (CZECHOWSKI et al. 2012), which is consistent with our observations, as the ground near the gentians was usually quite sandy, with bare patches thinly covered by plants. The site in the NNP therefore appeared to 
represent the dry extreme of habitats in which $P$. alcon used G. pneumonanthe.

Even more surprising was the presence of $P$. alcon in a M. schencki colony. Individuals of $P$. alcon are intensively tended and carried all the time by ant workers in the nests (THOMAS 1995). Therefore, the possibility that our observation was accidental is unlikely, but we cannot rule it out completely. According to THOMAS et al. (2005), a nesting place is sometimes deserted by a host colony, leaving Phengaris pupa/pupae behind, and another Myrmica species occupies the vacated site. Something like this could have occurred in the case of the prepupa we found.

This single observation could suggest the existence of a unique host race, taking into consideration the high degree of specificity of $P$. alcon observed both in the field (SIELEZNIEW \& STANKIEWICZ-FIEDUREK 2009) and in captivity (SIELEZNIEW $\&$ STANKIEWICZ 2007). It could also reflect the potential ability of hygrophilous $P$. alcon to switch to xeric habitats. Interestingly, SIELEZNIEW \& STANKIEWICZ (2004a) also report the occasional use of G. cruciata, i.e. the larval food plant of the xerophilous form of P. alcon by the population supported by $G$. pneumonanthe and M. scabrinodis. Both atypical records are therefore concordant with the hypothesis of SIELEZNIEW et al. (2012) suggesting that the hygrophilous form could be an ancestor of the xerophilous form.

However, our observations from 2014 did not confirm the findings from the previous season concerning host ant specificity and indicated a rather stereotypical situation. Even the infestation rate of M. scabrinodis colonies (33.6\%) was very similar to that of other Polish sites (31.8\%) during a study by a co-author of the present article (M.S.) (SIELEZNIEW $\&$ STANKIEWICZ-FIEDUREK 2009). It would therefore seem that $M$. schencki is of secondary importance for this local population of $P$. alcon. In artificial nests of $M$. schencki only two of 43 (5\%) early fourth instar caterpillars of $P$. alcon survived the first eight weeks (for comparison the survival rate in $M$. scabrinodis colonies was about $87 \%$ ), which indicates a very low probability of successful development in colonies of this species (SIELEZNIEW \& STANKIEWICZ 2007). In our fieldwork the contrasting results obtained from two seasons could also illustrate how the results of studies on host ant specificity could be affected by the sampling design, i.e. the precise marking of the area where larvae develop on plants (performed in 2014) is very important in order to obtain reliable data, and year. Further studies at the same site would be interesting in order to monitor possible variation in host ant use between seasons, and in relation to weather conditions and the distribution of flowering larval food plants.

The average number of eggs laid by a female $P$. alcon is estimated at about one hundred (KÖRÖSI et al. 2008). Presumably, therefore, the population of imagines consisted of no more than several dozen individuals. Hence, it is possible that in 2014 we examined most of the infested nests present at the site. This population undoubtedly depends on a very limited supply of the resources vital for its successful development (i.e. larval food plants and host 
ants) and is therefore very sensitive to habitat changes. The area of the mineral island used to be grazed by cattle, and it is possible that the gentians survived only in the patches of sparse vegetation that are suboptimal for $P$. alcon because of its low humidity. Very few larval food plants, which incidentally were practically ignored by the butterfly, were present in the northern part of the site, where the vegetation was richer in flowers and which generally seemed more appropriate as a habitat for G. pneumonanthe. However, as this vegetation was very dense, G. pneumonanthe may not have been able to germinate there, so its population was declining because of the gradual disappearance of ageing plants. If this is true, then the butterfly can survive only in suboptimal conditions and the population is on the verge of extinction at the moment.

One can also expect a reduced genetic variability (and therefore also possibly fitness) of this highly isolated population, similar to that detected in the population of Phengaris arion (LINNAEUS, 1758) inhabiting the mineral island in the Biebrza National Park, where wetlands appear to be a very effective barrier to gene flow (SIELEZNIEW \& RUTKOWSKI 2012). The population of $P$. alcon in NNP is therefore an interesting subject for further study, also from the standpoint of population ecology and genetics.

Above all, however, this site should be considered, within the NNP, as a priority target for conservation, not only for its status but also because it is separated from the nearest other locality of the butterfly by a distance of about $50 \mathrm{~km}$. The key issue seems to be an increase in the number of G. pneumonanthe plants in the northern part of the mineral island. We recommend small-scale sod cutting around the remaining reproductive individuals to allow G. pneumonanthe to germinate and establish seedlings (OOSTERMEIJER et al. 1998). The introduction of proper management for the whole potential habitat of $P$. alcon is also very important. Light grazing by cattle would be ideal; mowing with scythes, however, though rather less appropriate, in September or October, with some parts of the vegetation kept uncut every year, would also be beneficial.

\section{ACKNOWLEDGEMENTS}

We are grateful to the two anonymous reviewers for their valuable comments on the manuscript.

\section{REFERENCES}

Als T.D., NAsh D.R., Boomsma J.J. 2002. Geographical variation in host-ant specificity of the parasitic butterfly Maculinea alcon in Denmark. Ecological Entomology 27(4): 403-414. 
Als T.D., Vila R., Kandul N., Nash D.R., Hsu Yen, Mignault A., Boomsma J.J., Pierce N.E. 2004. The evolution of alternative parasitic life histories in large blue butterflies. Nature 432(7015): 386-390.

Barbero F., Thomas J.A., Bonelli S., Balletto E., Schönrogge K. 2009. Queen ants make distinctive sounds that are mimicked by a Butterfly Social Parasite. Science 323(5915): 782-785.

Bereczki J., Pecsenye K., Peregovits L., Varga Z. 2005. Pattern of genetic differentiation in the Maculinea alcon species group (Lepidoptera, Lycaenidae) in Central Europe. Journal of Zoological Systematics \& Evolutionary Research 43(2): 157-165.

Czechowski W., Radchenko A., Czechowska W., Vepsäläinen K. 2012. The Ants of Poland with Reference to the Myrmecofauna of Europe. Fauna Poloniae (New Series), Vol. 4. Natura optima dux Foundation, Warszawa.

Elmes G.W., Thomas J.A., Wardlaw J.C., Hochberg M.E., Clarke R.T., Simcox D.J. 1998. The ecology of Myrmica ants in relation to the conservation of Maculinea butterflies. Journal of Insect Conservation 2(1): 67-78.

Fric Z., Wahlberg N., Pech P., ZrzavÝ J. 2007. Phylogeny and classification of the PhengarisMaculinea clade (Lepidoptera: Lycaenidae): total evidence and phylogenetic species concepts. Systematic Entomology 32(3): 558-567.

FÜRST M.A., NASH D.R. 2009: Host ant independent oviposition in the parasitic butterfly Maculinea alcon. Biology Letters 6(2): 174-176.

KÖRÖSI K., ÖRVÖSSY N., BATÁRY P., KÖVÉR S., PEREGOVITS L. 2008. Restricted within-habitat movement and time-constrained egg laying of female Maculinea rebeli butterflies. Oecologia 156(2): 455-464.

Oostermeijer, J.G.B., LuiJten, S.H., Krenova, Z.V., Den NiJs, J.C.M. 1998. Relationships between population and habitat characteristics and reproduction of the rare Gentiana pneumonanthe L. Conservation Biology 12(5): 1042-1053.

SIELEZNIEW M., DZIEKAŃSKA I. 2009. Butterfly-ant relationships: Host ant specificity of Phengaris 'rebeli' HirschKe (Lepidoptera: Lycaenidae) in Pieniny Mts (southern Poland). Polish Journal of Ecology 57(2): 403-409.

SIELEZNIEW M., RUTKOWSKI R. 2012. Population isolation rather than ecological variation explains the genetic structure of endangered myrmecophilous butterfly Phengaris (=Maculinea) arion. Journal of Insect Conservation 16(1): 39-50.

Sielezniew, M., Rutkowski, R., Ponikwicka, D., Ratkiewicz, M., DZieKańsKa, I., Švitra, G. 2012. Differences in genetic variability between two ecotypes of endangered myrmecophilous butterfly Phengaris (=Maculinea) alcon - the setting of conservation priorities. Insect Conservation and Diversity 5(3): 223-236.

Sielezniew M., Stankiewicz A. 2004a. Gentiana cruciata as an additional host plant of Maculinea alcon on a site in Eastern Poland. Nota lepidopterologica 27(1): 91-93.

Sielezniew M., Stankiewicz A. 2004b. Simultaneous exploitation of Myrmica vandeli and M. scabrinodis (Hymenoptera: Formicidae) colonies by the endangered myrmecophilous butterfly Maculinea alcon (Lepidoptera: Lycaenidae). European Journal of Entomology 101(4): 693-696.

SielezNiew M., Stankiewicz A.M. 2007. Differences in the development of the closely related myrmecophilous butterflies Maculinea alcon and M. rebeli (Lepidoptera: Lycaenidae). European Journal of Entomology 104(3): 433-444. 
Sielezniew M., Stankiewicz-FiedureK A.M. 2009. Host ant use by Phengaris (=Maculinea) alcon in Poland. Polish Journal of Entomology 78(4): 323-335.

Stankiewicz A.M., Sielezniew M., Buszko J. 2005a. Maculinea alcon and M. rebeli in Poland: distribution, habitats, host ant specificity and parasitoids. [in:] J. SETTELE, E. KÜHN, J.A. ThOMAS (eds.). Studies on the Ecology and Conservation of Butterflies in Europe. Vol. 2: Species ecology along a European Gradient: Maculinea Butterflies as a Model. Pensoft Publishers, Sofia Moscow, 90-93.

StANKIEWICZ A.M, SieleZniew M., ŠvitRa G. 2005b. Myrmica schencki rears Maculinea 'rebeli' in Lithuania: new evidence for geographical variation of host-ant specificity of an endangered butterfly. Myrmecologishe Nachrichten 7: 51-54.

Tartally A., Koschuh A., Varga Z. 2014. The re-discovered Maculinea rebeli (HIRSChKe, 1904): Host ant usage, parasitoid and initial food plant around the type locality with taxonomical aspects (Lepidoptera, Lycaenidae). ZooKeys 406: 25-40.

Tartally A., Nash D.R., Lengyel S., Varga Z. 2008. Patterns of host ant use by sympatric populations of Maculinea alcon and M. 'rebeli' in the Carpathian Basin. Insectes Sociaux 55(4) 370-381.

THOMAS J.A. 1995. The ecology and conservation of Maculinea arion and other European species of large blue butterfly. [in:] A.S. PuLLin (ed.). Ecology and Conservation of Butterflies. Chapman and Hall, London, UK, 180-197.

Thomas J.A., Elmes G.W. 1998. Higher productivity at the cost of increased host-specificity when Maculinea butterfly larvae exploit ant colonies through trophallaxis rather than by predation. Ecological Entomology 23(4): 457-464.

Thomas J.A., Elmes G.W., Schönrogge K., Simcox D.J., Settele J. 2005. Primary hosts, secondary hosts and non-hosts: common confusions in the interpretation of host specificity in Maculinea butterflies and other social parasites of ants. [in:] J. SetTELE, E. KüHN, J.A. ThOMAS (eds.). Studies on the Ecology and Conservation of Butterflies in Europe. Vol. 2: Species ecology along a European Gradient: Maculinea Butterflies as a Model. Pensoft Publishers, Sofia - Moscow, 99-104.

Thomas J.A., Elmes G.W., Sielezniew M., Stankiewicz-Fiedurek A., Simcox D.J., Settele J., SchÖNROGge K. 2013. Mimetic host shifts in an endangered social parasite of ants. Proceedings of the Royal Society B: Biological Sciences 280: 20122336.

Witek M., Śliwinska E., Skórka P., Nowicki P., Wantuch M., Vrabec V., Settele J., Woyciechowski M. 2008. Host ant specificity of Large Blue butterflies Phenagris (Maculinea) (Lepidoptera: Lycaenidae) inhabiting humid grasslands in East-central Europe. European Journal of Entomology 105(5): 871-877.

Wynhoff I., Bakker R.B., Oteman B., ARnaldo, P., van Langevelde F. 2015. Phengaris (Maculinea) alcon butterflies deposit their eggs on tall plants with many large buds in the vicinity of Myrmica ants. Insect Conservation and Diversity 8(2): 177-188.

Received: 20 February 2015

Accepted: 2 April 2015 